\title{
Disentangling the Impact of International Migration on Food and Nutrition Security of Left-Behind Households: Evidence from Bangladesh
}

\author{
Donato Romano $^{1} \cdot$ Silvio Traverso ${ }^{1}$ (i)
}

(c) European Association of Development Research and Training Institutes (EADI) 2019

\begin{abstract}
This paper explores the linkages between international migration and household food and nutrition security (FNS). First, building on existing literature, we discuss the main microeconomic channels through which international migration may affect household FNS. Second, taking Bangladesh as a case study, we estimate the overall impact of international migration on the FNS of left-behind households. Third, by disentangling the overall effect, we assess the importance of the various microeconomic channels that link international migration to household FNS. The empirical results suggest that international migration has a positive impact on the quantity, quality and variety of food consumed by left-behind households. Our findings also suggest that international migration might be considered among the possible drivers of the so-called Bangladesh paradox, i.e. the exceptional progress in health and nutrition achieved by the country during a period of relatively poor economic performance.
\end{abstract}

Keywords International migration · Food and nutrition security · Propensity score matching $\cdot$ Bangladesh

\section{Résumé}

Cet article étudie les liens entre la migration internationale et la sécurité alimentaire et nutritionnelle (SAN) des ménages. Premièrement, en s'appuyant sur la littérature existante, nous examinons les principaux canaux microéconomiques par lesquels les migrations internationales peuvent avoir une influence sur la SAN des ménages. Deuxièmement, en prenant le Bangladesh comme étude de cas, nous estimons l'impact global de la migration internationale sur la SAN des ménages les plus démunis. Troisièmement, en distinguant l'effet global, nous évaluons l'importance des différents canaux microéconomiques qui relient la migration internationale à la

Silvio Traverso

silvio.traverso@unitn.it

1 Department of Economics and Management, University of Florence, Firenze, Italy 
sécurité alimentaire des ménages. Les résultats empiriques suggèrent que la migration internationale a un impact positif sur la quantité, la qualité et la variété des aliments consommés par les ménages les plus démunis. Nos résultats suggèrent également que la migration internationale pourrait être considérée comme l'un des facteurs possibles du prétendu "paradoxe du Bangladesh", à savoir les progrès exceptionnels réalisés par le pays en matière de santé et de nutrition pendant une période de performance économique relativement médiocre.

JEL Classification F22 $\cdot$ I1 $\cdot$ I3 $\cdot$ O15

\section{Introduction}

Over recent decades, international migration has become an increasingly relevant global phenomenon. According to official statistics, the number of international migrants has tripled over the last 45 years while migrants' remittances have reached about the same size as foreign direct investments (IOM 2018; World Bank 2018).

Even though the literature on migration and development is vast, few works have focussed on the nexus between migration and food and nutrition security (FNS). Indeed, while the development literature has studied in depth the effects of migration and remittances on poverty (Barham and Boucher 1998; Lokshin et al. 2010; Jimenez-Soto and Brown 2012; Adams and Cuecuecha 2013; Bertoli and Marchetta 2014; Wagle and Devkota 2018) and on different types of investment in left-behind households (Mendola 2008; Yang 2008; Adams and Cuecuecha 2010; Giannelli and Mangiavacchi 2010; Böhme et al. 2015), it has paid little attention to FNS issues (Zezza et al. 2011). Symmetrically, the implications of international migration have often been overlooked by studies on household FNS (Crush 2013).

This paper contributes to bridging the gap between these two distinct strands of literature and, by taking Bangladesh as a case study, investigates the extent to which international migration affects the FNS of left-behind households. First, building on existing literature, we discuss the microeconomic channels through which international migration may affect the different dimensions of household FNS, i.e. via the change in the household composition, via remittances, and via the change of household food consumption habits induced by returned migrants. Second, by adopting a broad definition of migrant households that encompasses remittance-recipient households as well as households having a member currently abroad or a returned migrant, we estimate the overall effect of international migration on the FNS of leftbehind Bangladeshi households. Third, we disentangle this overall effect by assessing the stand-alone relevance of each transmission channel.

We focus on Bangladesh for two main reasons. On the one hand, it is the country that, in absolute terms, recorded the highest outflow of migrants during the $2000 \mathrm{~s}$ and, in 2015, had the fifth largest stock of international migrants in the world (IOM 2018). On the other hand, over the last 25 years, Bangladesh has recorded the best performance in terms of improvement of several health and FNS indicators in the 
whole South-Asian region, managing to close the gap with its richer neighbours. ${ }^{1}$ As this progress occurred during a period of relatively slow economic growth, the country has attracted the attention of several scholars who have tried to find an explanation for such a 'Bangladesh paradox' (Chowdhury et al. 2013). While this literature has emphasized the role played by private stakeholders committed to inclusive development such as local and international non-governmental organizations (NGOs) (Asadullah et al. 2014) and has identified the pro-poor economic growth, the improvement of the status of women, the rapid increase in children's schooling as well as the improvements in sanitation and changes in neo- and antenatal care practices as the major drivers of Bangladesh's progress in the field of health and nutrition (Headey et al. 2015), it seems to have somehow overlooked the potential contribution of international migration. Although a fully fledged analysis of the relationship between international migration and the Bangladesh paradox is beyond the scope of this paper, our findings suggest that the former might be included among the possible drivers of the latter (or, at least, that this relationship deserves further exploration).

Our empirical analysis indicates that international migration has a positive and statistically significant effect on household FNS, with each transmission channel impacting at least one of the household FNS indicators considered in the analysis. Thanks to migration, households have access to more food and to a more diversified diet, shifting consumption towards food items that are richer in protein and micronutrients.

The remainder of the paper is organized as follows: Section 2 discusses the nexus between migration and household FNS, emphasizing the most relevant channels through which the former may affect the latter. Section 3 provides a brief overview of data and methods. Section 4 describes the empirical strategy. Section 5 reports the empirical findings, focussing, first, on the overall impact of international migration and, second, on the impacts of each microeconomic channel. Section 6 concludes.

\section{International Migration and Household FNS}

Household FNS has a multidimensional nature and can be influenced by migration in several ways. Indeed, as pointed out by Zezza et al. (2011, p. 5), the 'identification of causal relationships and the unpacking of the mechanisms through which the impacts of migration materialize' represent a key methodological challenge. Building on existing literature (Levitt 1998; Azzarri and Zezza 2011; Karamba et al. 2011; Crush 2013; Nguyen and Winters 2011; Warner and Afifi 2014), in this section we discuss the various channels through which international migration might affect the four dimensions of household FNS.

\footnotetext{
${ }^{1}$ The per capita caloric intake gap, which stood at $200 \mathrm{kcal} / \mathrm{day}$ in the early $1990 \mathrm{~s}$, disappeared by the second half of the 2000s, and the proportion of undernourished people rapidly declined from $37 \%$ to $16 \%$. Similarly, the prevalence of stunted and underweight children fell by more than one-third, child mortality dropped by two-thirds, and life expectancy at birth increased by about 10 years (World Bank 2018).
} 


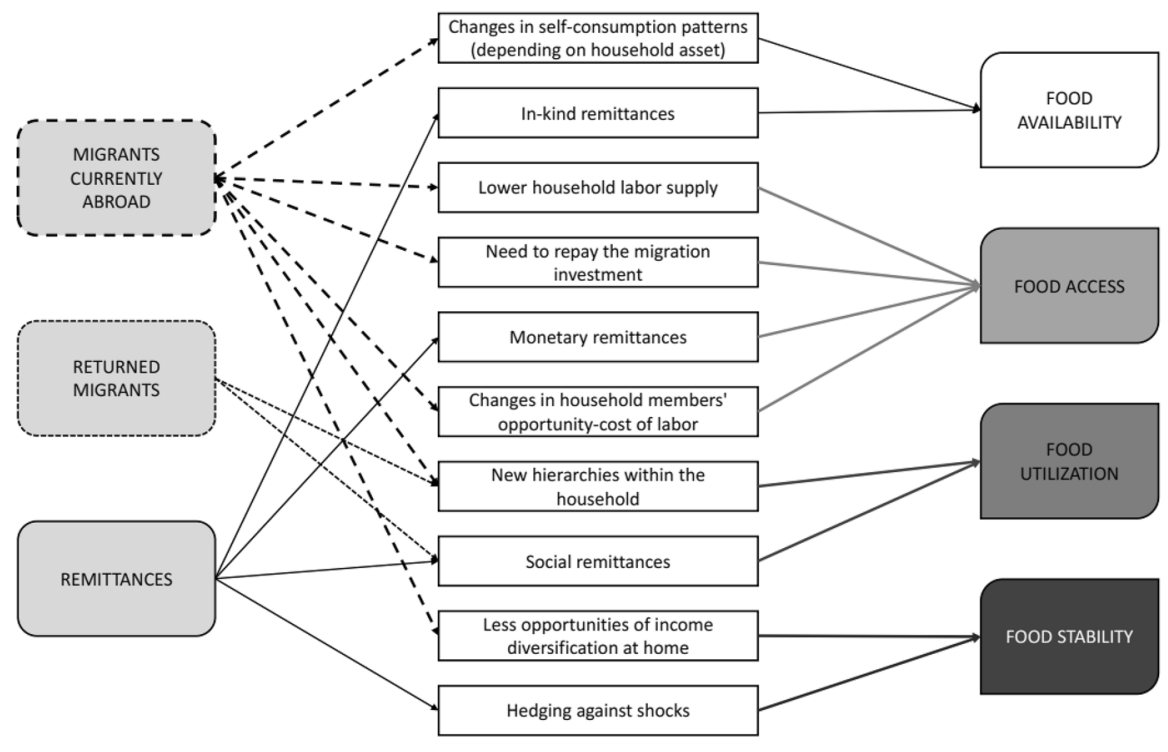

Fig. 1 How migration affects household food and nutrition security

First, the departure of a member leads to a new equilibrium within the household. Specifically, a change in household composition implies a change in the opportunity cost of household labour and a modification of the internal hierarchies (Mangiavacchi et al. 2018; Zhunusova and Herrmann 2018). Depending on the migrant's individual characteristics and the household's assets, it can influence food availability, food access and food utilization. The migrant's departure entails a reduction of household food requirements but also of total (potential) household labour supply. $^{2}$ In addition, if migration implies a shift in the household headship (often from the migrating husband to his wife), it can contribute to empowerment of women (Abdulloev et al. 2014) and influence the intra-household allocation of labour and consumption, thus affecting food security at both the household and individual level (Buvinić and Gupta 1997; Haddad et al. 1997; Quisumbing 2003; Alam 2012).

Second, households can receive overseas remittances. Even though in most cases remittances are received from a migrant household member, the sender can also be a friend or a relative who does not belong to the household. Remittances can have a direct impact on all the dimensions of food security. Whereas in-kind remittances increase food availability, monetary remittances enhance food access. Both types of remittances - if correlated with negative shocks - can enhance food stability because, as pointed out by the new economics of labour migration literature (NELM), migration can be interpreted as a household risk-diversification strategy when insurance and capital markets are incomplete or missing (Stark and Bloom

\footnotetext{
${ }^{2}$ For instance, in a context such as the over-populated rural Bangladesh, which has only recently approached the Lewis turning point (Zhang et al. 2014), reducing the number of household members at home may increase per capita food availability (especially for large subsistence farming households).
} 
1985). Finally, migrants might influence the utilization dimension by inducing new food consumption habits at home through social remittances (Levitt 1998).

Third, consumption patterns of the household may be influenced by the presence of a returned migrant. Indeed, the returnee can introduce new food habits acquired abroad, thereby influencing the household food utilization dimension. This transfer of knowledge represents another, and possibly stronger, mechanism of social remittances. Moreover, the prolonged absence of a member may irreversibly alter the hierarchies within the household and, after his return, the internal equilibrium of the family may substantially differ from the one prior to migration.

The overall effect jointly produced by the above-mentioned transmission channels, summarized in Fig. 1, cannot be determined a priori and depends on the specific circumstances in which each migration episode takes place; For example, if the migrant is not able or willing to remit, the negative effects may offset the positive ones. On the other hand, anticipating an increase in their future income, some households may be induced to increase their level of consumption even before receiving remittances.

\section{Data and Methods}

\section{Data}

Our analysis is based on the 15th round of the Bangladesh Household Income and Expenditure Survey (HIES 2010), carried out in 2010-2011 by the Bangladesh Bureau of Statistics (BBS). The survey gathers information on 12,240 households distributed across 612 sampling units and 16 strata. It collects a wide range of socioeconomic information at both the individual and household level, and it is representative at both national and regional level.

HIES surveys are the primary source of information on Bangladeshi households. The consumption modules of HIES 2010 include information on the quantity, value and origin of 145 different food items aggregated into 17 main categories. These data, collected through seven interviews over 14 consecutive days, can be used to compute quantitative indicators of household FNS, e.g. daily per capita food expenditure or caloric intake, as well as measures of dietary diversity, e.g. the Gini-Simpson and normalized Shannon indices, that can be used as proxies of household diet quality.

Differently from the previous waves, HIES 2010 includes also detailed information on migration and remittances. Specifically, for each migrant, it provides individual information regarding his socio-demographic status (e.g. age, gender, and literacy), migration and remittances. Moreover, the survey provides an estimation of the total value of the remittances received over the previous 12 months from friends and relatives living abroad. Finally, with specific reference to international migration, the survey asks whether any of the members present at the time of the interview has been abroad for at least six consecutive months during the previous 5 years and, if so, the reason why he/she returned home.

Historically, most Bangladeshi migrant workers have moved to oil-rich Gulf countries that adopted policies aimed at attracting cheap unskilled labour and favouring 
remittances (Mehlum and Østenstad 2016). The nominal value of overseas remittances increased by a factor of seven between 2000 and 2012, when they were worth about $12 \%$ of gross domestic product (GDP) and almost half of total export value.

The total number of households directly affected by international migration is 1445 , i.e. $11.8 \%$ of the sample. The households involved in international migration seem to perform systematically better in terms of FNS compared with those not involved in international migration (Table 1). Migrant households are also relatively larger in size and more educated than their non-migrant counterparts. ${ }^{3}$

\section{Definition of Treatments}

Estimating the overall impact of international migration on the FNS of left-behind households and disentangling this impact by assessing the effect of the various microeconomic transmission channels require the definition of two different sets of treatment states.

The overall impact of international migration on household FNS can be evaluated by defining an active treatment that includes all households that have been affected directly by international migration. More specifically, the households exposed to the active treatment are identified as those households that, at the time of the survey, fulfil at least one of the following conditions: (i) a member of the household is abroad, (ii) the household received monetary remittances from abroad over the previous 12 months, and (iii) a member of the household currently at home has been abroad for at least six consecutive months over the previous 5 years.

On the other hand, estimating the impact of the stand-alone microeconomic transmission channels requires the definition of four active treatment states, namely: ${ }^{4}$

- Treatment group 'A', meant to capture the effect of the change in household structure, includes those households that reported having a migrant member currently abroad but did not receive monetary remittances over the past 12 months and did not have an international returnee among its members (153 obs.);

- Treatment group 'B', meant to capture only the effect of receiving monetary remittances, encompasses the households that, although having neither migrants currently abroad nor a returned migrant, did receive remittances from abroad over the past 12 months (154 obs.);

- Treatment group ' $\mathrm{C}$ ', meant to capture only the effect of returned migrants, includes the households having at least one of its members present at the time of the interview who had been abroad for six consecutive months over the past 5 years but currently not having members abroad and to have not received remittances over the previous 12 months (122 obs.);

- Treatment group 'D', meant to capture the joint effect of migration and remittances, encompasses the households that have received monetary remittances over the previous 12 months and currently have a member abroad but do not have any returned migrant among its members (952 obs.).

\footnotetext{
3 A more detailed discussion of household self-selection can be found in Sect. 4.4.

4 The treatments 'migrants+returnees', 'remittances+returnees' and 'migrants+remittances+returnees' include only 64 households and are not considered in the analysis.
} 
Finally, the passive treatment state contains the large pool of non-treated households that are households with no international migration experience, no matter whether current or past (10,795 obs.).

\section{Definition of Outcome Variables}

FNS is an inherently multi-dimensional construct that cannot be fully captured by a single measure. Over the years, the literature has proposed several indicators, each of them capturing some of the dimensions of food and nutrition security (Masset 2011; De Haen et al. 2011; Carletto et al. 2013). Given the lack of available anthropometric data in HIES 2010, this study relies on indicators that can be computed using household-level information on nutritional inputs and consumption behaviour. Specifically, we measure household FNS using a set of synthetic indicators including daily per capita food expenditure, daily per capita caloric intake, the normalized Shannon index, and the Gini-Simpson index.

Per capita food expenditure and per capita caloric intake are computed from HIES consumption modules. Whereas the estimation of food expenditure is straightforward, the computation of the caloric intake requires some assumptions. Indeed, even though the BBS provides the caloric conversion factor for each food item quantity, some of them are reported in units (e.g. number of eggs, chocolate snacks, cups of chai, etc.) for which the weight/volume has been assumed. ${ }^{5}$

The Shannon index and the Gini-Simpson index are two of the most common measures of diversity that, in the context of migration and food security studies, have already been employed by Nguyen and Winters (2011). Formally, they are defined as

$$
\begin{gathered}
I_{\text {Shannon Norm }}=\frac{\sum_{c=1}^{C} s_{c} \ln \left(s_{c}\right)}{\max \left(\sum_{c=1}^{C} s_{c} \ln \left(s_{c}\right)\right)} \times 100, \\
I_{\text {Gini-Simpson }}=\left(1-\sum_{c=1}^{C} s_{c}^{2}\right) \times 100,
\end{gathered}
$$

with $c=\{1,2, \ldots, C\}$ indexing the food categories and $s_{c}$ describing their relative share of either total food expenditure or total caloric intake. The two indices range from 0 to 100 , with a higher value being associated with a higher degree of diversity. The measurement of dietary diversity is relevant because diet diversification has proven to be a robust proxy for households' food security as well as for child nutrition (Hoddinott and Yohannes 2002; Thorne-Lyman et al. 2009). In particular, also controlling for socio-economic factors, dietary diversity is significantly correlated with children's height-for-age (Arimond and Ruel 2004). In general, food expenditure and caloric intake are considered proxies for food access and food availability,

\footnotetext{
${ }^{5}$ However, these items are relatively few and represent a negligible share of the total caloric intake. For instance, on average, eggs represent only $0.44 \%$ of daily caloric intake.
} 
while dietary diversity measures are regarded as proxies for food utilization. Unfortunately, the cross-sectional nature of the data and the lack of anthropometric measures prevent the analysis of food stability.

\section{Empirical Strategy}

\section{Methodological Issues in Migration Studies and Matching}

The microeconomic assessment of the impact of migration raises a series of methodological issues. Following the taxonomy of Adams (2011), the main issues can be identified as those arising from (i) the simultaneity of the migration decision with other decisions, such as household labour supply and fertility, which may also influence the outcome of the variable(s) of interest, (ii) the self-selection of migrants, who may differ systematically from stayers, (iii) the reverse causality between FNS and migration, and (iv) the presence of relevant omitted/unobservable variables. Within non-experimental settings, these issues can be addressed by means of instrumental variable (IV) estimators, but when data availability and/or concerns regarding the validity of the exclusion restriction limit the scope of this approach, matching represents a fair alternative.

Matching methods have increasingly been used in migration studies (Ham et al. 2011; Jimenez-Soto and Brown 2012; Bertoli and Marchetta 2014; Möllers and Meyer 2014), and if the size and quality of the dataset are good enough, matching is regarded as an empirical strategy fairly capable of dealing with the aforementioned issues. Indeed, by comparing the results obtained using a set of commonly used non-experimental estimators with a benchmark treatment effect estimated by taking advantage of a natural experiment, McKenzie et al. (2010) found that matching methods represent the best non-experimental solution after IV. However, they also pointed out that matching methods may not be able to fully remove the bias introduced by migrants' self-selection. Yet, the specification of McKenzie et al. (2010) did not include any information on the household of origin, and neglecting the relevance of household characteristics in determining individual outcomes and migration decisions is at odds with one defining aspect of the NELM approach (Stark and Bloom 1985). Vice versa, the specification adopted in this study (see Sect. 4.3) includes several variables related to the household socio-demographic composition that can be considered exogenous to the treatment(s) and that, at the same time, turn out to be significantly correlated with both the outcome variables and the probability of migrating.

\section{Matching Strategy}

Matching methods rely on the idea that the effect of a treatment can be estimated by comparing the outcome of interest between units which share the same observable characteristics but have been exposed to different treatment states. This strategy has a long tradition, but it became popular after Rosenbaum and Rubin (1983) showed 
that when - after conditioning on all the relevant confounding factors $X$-the potential outcomes are orthogonal to treatment assignment, they will also be orthogonal to the assignment after conditioning on a balancing score. Balancing scores are functions of $\boldsymbol{X}$, and among them, the propensity score (defined as a function $f: \mathbb{R}^{n} \rightarrow \mathbb{R}$ of the confounding variables that indicates the probability of treatment assignment) is the most frequently used. Formally, considering $Y^{0}$ and $Y^{1}$ as the potential outcomes of a generic unit under a dichotomous treatment $D=\{0,1\}$, if the conditional independence assumption

$$
\left(Y^{0}, Y^{1}\right) \perp D \mid X
$$

holds, then

$$
\left(Y^{0}, Y^{1}\right) \perp D \mid f(\boldsymbol{X})
$$

is also true. Given that $f(\boldsymbol{X}) \in \mathbb{R}$, by providing a solution to the "curse of dimensionality', i.e. the fact that, as the dimension of $\boldsymbol{X}$ increases, the probability of finding exact matches rapidly falls to 0, Rosenbaum and Rubin (1983) significantly widened the scope of matching applications. Indeed, the average treatment effect on the treated

$$
A T T=E\left(Y^{1}-Y^{0} \mid D=1\right)
$$

can be estimated by taking the average outcome difference between the treated and the matched controls, i.e. untreated units with (ideally) the same value of the balancing score. Following Rubin (2001), we matched on the estimated linearized propensity score (lps), that is the logarithm of the odds of the propensity score. It is formally defined as

$$
\ell(\boldsymbol{X})=\ln \left(\frac{e(\boldsymbol{X})}{(1-e(\boldsymbol{X}))}\right),
$$

where $e(\boldsymbol{X})$ indicates the propensity score. By removing the non-linearity of the propensity score, the lps entails two main advantages. On the one hand, it guarantees the consistency of all the matching estimators based on the linear distance between individual scores such as nearest neighbour, caliper and kernel (Rubin 2001; Imbens and Rubin 2015). ${ }^{6}$ On the other hand, it allows easy identification of the region of common support by imposing a caliper (Austin 2011).

The empirical part of the study consists of two steps: first we evaluate the overall effect of international migration on household FNS, then we estimate the impact of the different channels through which the former affects the latter.

To assess the overall effect of international migration on household FNS, we partition the sample into four strata/blocks on the basis of the regional food poverty lines provided by the BBS, then we perform matching within each stratum. We

\footnotetext{
${ }^{6}$ Let us take, for instance, a treated unit with an estimated propensity score ( $\left.p s\right)$ of 0.10 and two potential matches, (a) and (b), with an estimated ps of 0.08 and 0.12 , respectively. Since the algorithms usually available in statistical packages (e.g., NN, radius, and kernel) perform matching on the linear distances between the scores, (a) and (b) would be erroneously considered as 'equally close' matches, even though, because of the non-linearity of the $p s$, (b) should be considered closer. By linearizing the distances on which matching is performed, the lps addresses this issue; indeed, in the example above, (b) is correctly identified by the algorithm as a better match than (a).
} 
obtain the final results by adding up the estimates of each stratum and by re-estimating the standard errors for the whole population. Such a within-strata matching procedure partly addresses the heterogeneity stemming from households' nonspecific identifying features (e.g. the confounding factors related to the region where they live), allowing us to estimate the balancing score on the basis of households' individual characteristics only (Cox 1992). Specifically, this procedure ensures that migrant households are matched only with controls that live in areas where food prices are similar, and therefore that the treatment effect is not due to monetary illusion. This is particularly relevant since some of our outcome variables are expressed in monetary terms, food prices exhibit non-negligible variability across strata, and the intensity of migration is not uniformly distributed across Bangladesh. ${ }^{7}$

In order to estimate the impact of the different channels through which international migration affects the FNS of left-behind households, we adopt the multiple treatment generalization of the Rubin causal model developed by Lechner (2002). In this case, the definition of 5 alternative treatments ( 4 active +1 passive) implies that it is possible to estimate 20 different treatment effects, one for any possible pairwise permutation of treatment states (e.g. the effect of treatment $\mathrm{A}$ on units exposed to the passive treatment state, the effect of treatment $\mathrm{A}$ on units exposed to the treatment state B, etc.). ${ }^{8}$ However, given the aim of this analysis, we only evaluate the four active treatments against the passive one, i.e. the no-migration scenario. Because of the absence of an adequate proportion of treated units within each stratum, in this case we performed matching on the whole sample and addressed the problem of non-specific identifying features by including regional dummies. Since this procedure may not be able to fully address the estimation issues related to price differentials across regions, in this part of the analysis we focussed only on the FNS indicators based on caloric intake.

\section{Choosing the Matching Variables}

We estimate the propensity score using a probit model. The choice of the covariates to include in the model is a crucial step of the estimation strategy, since they are supposed to ensure the conditional independence of the potential outcomes. The matching covariates need to influence both the probability of migration and households' FNS without being influenced by the treatment. As a rule of thumb, variables whose value was already determined before the treatment (e.g. the number of adult household members and their level of schooling) can generally be considered as exogenous to migration.

Our final set of conditioning covariates $\boldsymbol{X}$ includes six variables meant to describe the demographic structure of the household, two variables describing the educational attainment of the adult members and five other variables related to

\footnotetext{
${ }^{7}$ However, as a robustness check, we report in the Appendix (Table 12) the estimates of the overall impact of international migration obtained including regional dummy variables (panel A) and the regional food poverty line (panel B) among the matching covariates. The results do not change significantly.

${ }^{8}$ The number of possible treatment effects is given by $P(2, n)=k ! /(n-2) !$, where $n$ is the number of treatment states.
} 
households' religion, non-agricultural business activities, land assets, access to the electricity grid and urban/rural status. In order to find consistent matches, we computed all the variables related to household education and demographic composition as if the migrants were present in the household at the time of the interview. We also included probability weights, since they carry household-specific information (Zanutto 2006). The inclusion of each covariate is discussed in the following paragraphs, while the probit regressions are reported in Tables 9 and 10 of the Appendix.

Partially departing from literature, our model includes six pre-treatment variables that describe the demographic composition of the household, i.e. the number of working-age women and men by two age groups, the number of elderly and the number of children between 6 and 17 (we left out younger children since their number may be endogenous to migration). These variables turn out to be highly significant in determining the probability of selection into treatment, and consistent with the NELM approach, their inclusion is meant to highlight the importance of the household structure in influencing the migration decision. Specifically, household size — and the number of adult males in particular-represents a key variable in determining the probability of migration: larger households have a higher probability of engaging in international migration. On the other hand, we did not include some demographic variables that have often been used in previous studies but may arguably be endogenous to migration; For example, we excluded the age-dependency ratio because migration is likely to influence households' fertility choices and, in turn, the ratio itself. ${ }^{9}$

We also included in the model, separately, the average educational attainments (in terms of years of schooling) of male and female adult members. These two pre-treatment variables correlate with the probability of migration and can be considered as proxies for the pre-migration economic condition of the household and for the unobserved ability of its members.

Our specification also includes two pre-treatment dummies indicating the household's involvement in either formal or informal business in the non-agricultural sector. ${ }^{10}$ These variables correlate with the pre-migration economic condition of the household and, very likely, with unobservable characteristics of the household head that affect the economic behaviour (and therefore the economic outcome) of the households (Welter 2011). The households' land assets could in principle be considered endogenous to

\footnotetext{
9 The empirical literature on migration has usually taken the household structure as exogenous with the exception of newly born members. Yet, as recently pointed out by Bertoli and Murard (2019), this may not always be the case. Indeed, using a panel of Mexican households, they found that migrant-sending households are more likely to receive a new member in the months following the migration episode. They also point out, however, that controlling for this issue is difficult because of the way standard survey questions are formulated, therefore calling for a revision of household questionnaires. While we acknowledge that endogenous household recomposition may introduce a bias into our estimates, we also argue that our only option is to stick with the exogeneity assumption because of the lack of specific survey questions in the HIES 2010. Otherwise, we should drop all the variables that are associated with characteristics of the household members.

${ }^{10}$ In the case of migrant households, the dummies take a value of 1 only if the business was already running before migration.
} 
migration, but given the tight land market of Bangladesh (Mendola 2008), a 'landless dummy' can be included as a proxy for households' pre-migration income level.

Finally, unlike other works (Möllers and Meyer 2014; Jimenez-Soto and Brown 2012; Calero et al. 2009), our set of matching covariates does not include any variable directly related to the household head. Indeed, even though some characteristics of the head can arguably influence households' outcomes, the headship should be considered endogenous to migration. In fact, female-headed households are significantly more frequent among migrant households, but at the same time, almost all migrants are male and one out of three is registered as husband of the household head, suggesting that the headship shifted to the wife after the husband's migration (Kabeer et al. 2018).

A final comment is in order about the specification of the probit model for treatment ' $C$ ', where the level of per capita expenditure has also been included. This is justified by the fact that the treatment group ' $\mathrm{C}$ ' is related to a different stage of the migration process, and not conditioning for the level of per capita expenditure, the ATT would capture the long-term cumulative effect of migration, possibly remittances, and the presence of returnees rather than only the latter. It should be noted that, only in this case, given the definition of treatment ' $C$ ', the expenditure can be considered as exogenous.

\section{Self-Selection of Migrant Households}

Matching methods rely on selection on observables, thus it is worth checking which household characteristics are associated with a higher probability of migration (Table 2). In general, migrant households are positively self-selected in terms of household size and of education level of the adult members, especially women. Moreover, migrant households are more likely to be Muslim, whereas they are less likely to run an informal business and to be landless. Migrant households tend to live in non-urban areas and where the public electricity grid is available. About onethird of migrant households live in the region of the capital city, Dhaka, but this proportion is largely in line with the overall demographic distribution of the country. Conversely, migrant households are strongly and positively self-selected among those living in the south-eastern coastal region of Chittagong, the economic and financial centre of the country, while relatively few migrant households originate from divisions where the income level is below the country average, i.e. Rangpur, Barisal, Rajshai and Kulna.

\section{Matching Robustness}

We performed matching using a nearest-neighbour caliper estimator $(n=3)$ with replacement. Different matching estimators, such as simple nearest neighbour, radius and kernel, produce similar results (cf. Table 11 in the Appendix). ${ }^{11}$

\footnotetext{
11 The reason for choosing the nearest neighbour is mainly practical: this estimator attaches integer weights to matched units and therefore it makes easier to handle the control group.
} 
Table 3 reports some statistics describing the quality of the matches. After matching, both the mean and median bias of the covariates are significantly reduced. Specifically, the mean bias is always below the 5\% threshold except for stratum number 4, in which it decreases from $24.0 \%$ to $6.8 \%$. In order to estimate the overall impact, we dropped 40 observations ( $2.8 \%$ of the migrant households) that were outside the region of common support. In estimating the impact of each microeconomic channel, however, only one household fell outside the overlapping region.

The pseudo- $R^{2}$ and the $p$ value of the LR test for joint significance of the coefficients of the probit regression on matched and unmatched samples indicate that the lps has been able to ensure the orthogonality of treatments and covariates. In all cases, the goodness of fit of the matched probit is not substantially different from zero and the hypothesis of joint significance of its coefficients is always rejected.

Finally, even though our research focusses on international migration, internal migration also represents a common household strategy that may lead to a significant improvement in household consumption (Bryan et al. 2014). Considering that, to a certain extent, domestic and international migration may be seen as substitutes, we also check whether the proportion of households with domestic migrants is similar between treatment and control groups. On average, $6.2 \%$ of international migrant households also report domestic migrants, while this percentage drops to $4.6 \%$ among households without international migrants. However, this proportion increases to $5.5 \%$ among matched controls, not statistically different from that of migrant households. ${ }^{12}$

\section{Results}

\section{Aggregate Impact of International Migration on Household FNS}

The estimates of the overall impact of international migration on household FNS (Table 4) are largely consistent with previous findings (Azzarri and Zezza 2011; Nguyen and Winters 2011; Böhme et al. 2015) and suggest that international migration has a positive and statistically significant effect on all considered indicators. Specifically, migrant households' diet increases in terms of both quantity $(+276 \mathrm{kcal} / \mathrm{capita} /$ day, $+11.9 \%)$ and variety (Shannon and Gini-Simpson indexes rise from 53.19 to 59.48 and from 48.80 to 54.71 , respectively). The impact of international migration on food expenditure is qualitatively similar but higher in relative terms.

From a FNS viewpoint, international migration allows households to consume more food and to have access to a more diversified diet. Moreover, the fact that the percentage increase in per capita food expenditure $(+24.6 \%)$ is larger than the corresponding increase in caloric intake $(+11.9 \%)$ indicates that migration induces a

\footnotetext{
12 The $p$-value of the test is $34.1 \%$. As a further check, we also dropped all the households that reported internal migrants and re-estimated the effect of international migration on household FNS, obtaining not statistically different results.
} 
shift in household consumption towards superior foods. However, this result refers to an unweighted basket of food items. We can better assess the quality improvement in food consumption by comparing the changes of expenditure and quantity of each food category.

By disaggregating the overall impact on the quantity consumed of specific food items (Table 5), we find that international migration produces a two-digit increase for all food categories, except 'Food grains' and 'Dining out'. Notably, the three largest increases in consumption indicate a switch towards animal protein-rich products such as 'Milk and dairy' (+ 75.2\%), 'Meat' (+ 66.7\%) and 'Eggs' $(+56.7 \%)$. Similarly, the changes in the consumption of 'Vegetables' $(+15.5 \%)$, 'Fruits' $(+33.8 \%)$ and 'Oil and fats' $(+35.9 \%)$ suggest a significant increase in the intake of fundamental vitamins and micronutrients. 'Food grains' remains the primary source of calories but records only a modest (and not significant) increase in the quantity consumed $(+4.0 \%)$ and a decrease of 4.9 percentage points in the household food basket share. 'Dining out' is the only category that is negatively affected by migration $(-16.8 \%)$. The interpretation of this result is difficult in the absence of more specific information on household eating behaviour. However, considering that 98.4\% of international migrants are males, one-third of them are likely to be the former household head, and the Bangladeshi cultural environment, we interpret this as a consequence of the fact that male migration translates into a reduced opportunity to go dining out for the rest of the family, especially for women.

The impact of international migration on item-wise food expenditure (Table 6) mirrors that on caloric intake. Specifically, the impact is always positive except for 'Dining out' and 'Tobacco and tobacco products', whose ATT exhibit a negative sign, although the latter is not significant at conventional confidence levels. 'Milk and Dairy', 'Meat', 'Fruits', 'Drinks' and 'Sugar' are the food categories exhibiting the highest percentage increases.

Comparing the effect on caloric intake with the effect on food expenditure provides insights into the changes in the quality of food consumed by migrant households. Indeed, the difference between the percentage changes in expenditure and in quantity approximates the percentage change in the prices of the products, a proxy for changes in the average food quality. For instance, migrant households shift their consumption toward more expensive varieties of 'Fruits' and 'Pulses' $(+15.4 \%$ and $+14.4 \%)$.

Finally, comparing the observed and counterfactual distributions of migrant households' (log) per capita food expenditure and the Gini-Simpson index calculated on food expenditure (Fig. 2), we see that international migration shifts the two distributions to the right, thus contributing to improved household FNS. However, the non-parametric nature of the estimates highlights the risky nature of international migration. Indeed, the observed distributions have (slightly) fatter left tails, indicating that migration 'went wrong' for some households and induced a deterioration of FNS.

These results are relevant for two reasons. First, they provide further and more detailed evidence confirming the positive impact of international migration on leftbehind households' FNS. Second, considering the established relation between an adequate diet and physical growth, mental development and health status of 

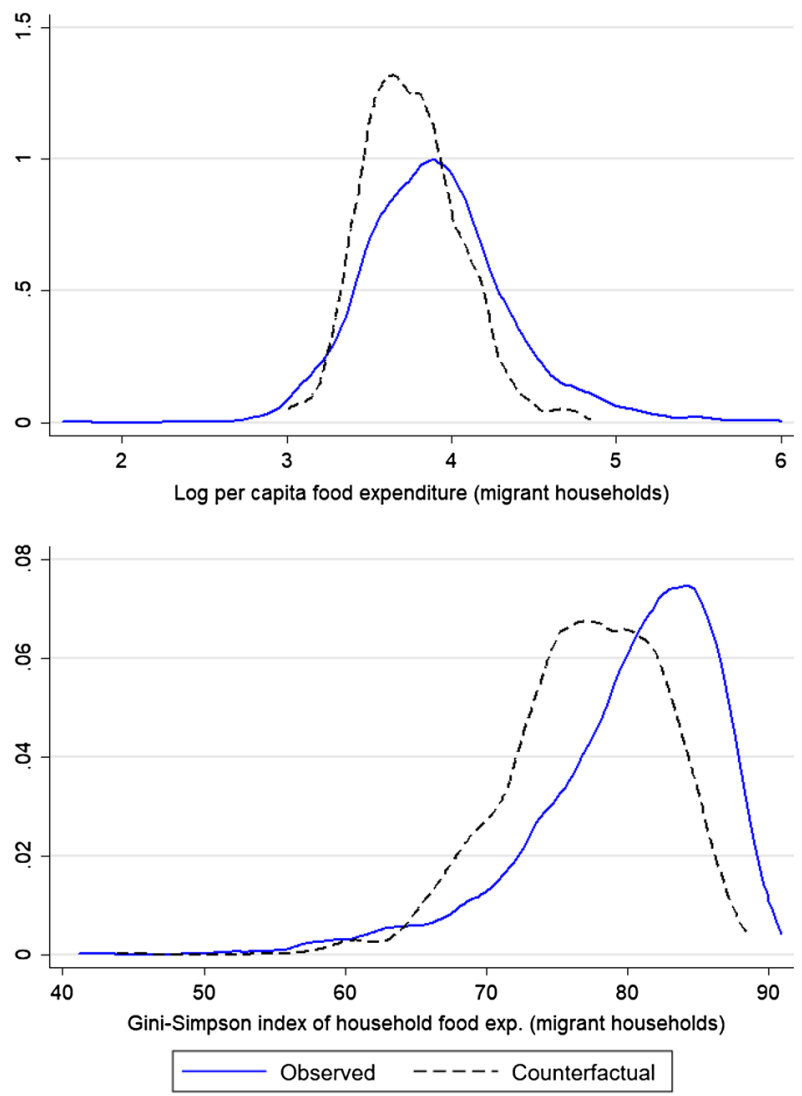

Notes: the figure reports the observed and the estimated counterfactual distributions of log per capita caloric intake (upper panel) and food expenditure Gini-Simpson index (lower panel) for migrant households.

Fig. 2 Per capita caloric intake and dietary diversity of migrant households: observed versus counterfactual

household members - and of children and pregnant women in particular (Hoddinott and Yohannes 2002; Arimond and Ruel 2004; Headey 2013)_the results suggest that migration may have played a role in the remarkable health improvements experienced by Bangladesh during the 1990s and 2000s.

\section{Consumption of Tobacco, Self-Selection and Female-Headed Households}

The effect of international migration on per capita consumption of tobacco turns out to be negative (though not significant at conventional confidence levels). Although there are no previous studies on the effect of migration on the consumption of tobacco in Bangladesh, our finding is consistent with those of Quisumbing and McNiven (2010) and Nguyen and Tran (2014) in the Philippines 
Table 1 Selected household summary statistics

\begin{tabular}{llll}
\hline & Full sample & Non-migrant & Migrant \\
\hline P.c. caloric intake (kcal/day) & 2387 & 2361 & 2582 \\
Norm. Shannon (cal. intake) & 53.29 & 52.46 & 59.47 \\
Gini-Simpson (cal. intake) & 49.29 & 48.57 & 54.66 \\
P.c. food expenditure (taka/day) & 45.11 & 43.69 & 55.76 \\
Norm. Shannon (food exp.) & 71.66 & 71.09 & 75.86 \\
Gini-Simpson (food exp.) & 76.61 & 76.15 & 80.03 \\
Share of food exp. in tot. exp. & 0.57 & 0.58 & 0.51 \\
Schooling (avg. years, adults) & 4.14 & 4.03 & 4.96 \\
Household size & 4.54 & 4.51 & 4.79 \\
Observations & 12,240 & 10,795 & 1445 \\
\hline
\end{tabular}

Households are grouped according to the definition of 'migrant households' provided in Sect. 3.2

Table 2 Self-selection of international migrant households

\begin{tabular}{lllllll}
\hline & Non-migrant & Migrant & Treat. A & Treat. B & Treat. C & Treat. D \\
\hline Adults 18-45 (female) $^{\mathrm{a}}$ & 0.997 & 1.171 & 1.124 & 1.052 & 1.163 & 1.163 \\
Adults 18-45 (male) $^{\mathrm{a}}$ & 0.907 & 1.494 & 1.660 & 0.779 & 1.187 & 1.570 \\
Adults 46-65 (female) $^{\mathrm{a}}$ & 0.288 & 0.420 & 0.484 & 0.273 & 0.285 & 0.444 \\
Adults 46-65 (male) $^{\mathrm{a}}$ & 0.328 & 0.412 & 0.471 & 0.318 & 0.333 & 0.422 \\
Adults 65+ $^{\mathrm{a}}$ & 0.181 & 0.250 & 0.235 & 0.240 & 0.220 & 0.256 \\
Children 6-17 $_{\text {Schooling (avg. years, females) }} \mathrm{a}$ & 1.274 & 1.400 & 1.353 & 1.370 & 1.293 & 1.449 \\
Schooling (avg. years, males) $^{\mathrm{a}}$ & 3.503 & 4.552 & 4.651 & 4.956 & 5.751 & 4.277 \\
Muslim & 0.359 & 4.343 & 4.264 & 4.844 & 6.607 & 3.869 \\
Entrepreneurship (formal) $^{\mathrm{b}}$ & 0.065 & 0.949 & 0.941 & 0.942 & 0.927 & 0.952 \\
Entrepreneurship (informal) $^{\mathrm{b}}$ & 0.193 & 0.051 & 0.052 & 0.078 & 0.073 & 0.043 \\
Access to elec. grid & 0.552 & 0.102 & 0.072 & 0.195 & 0.236 & 0.074 \\
Landless $_{\text {Urban }}$ & 0.073 & 0.028 & 0.804 & 0.708 & 0.813 & 0.746 \\
Barisal (region) & 0.365 & 0.317 & 0.275 & 0.351 & 0.407 & 0.306 \\
Chittagong (region) & 0.083 & 0.053 & 0.013 & 0.078 & 0.033 & 0.061 \\
Dhaka (region) & 0.154 & 0.372 & 0.438 & 0.260 & 0.301 & 0.392 \\
Khulna (region) & 0.285 & 0.320 & 0.314 & 0.279 & 0.382 & 0.316 \\
Rajshahi (region) & 0.155 & 0.085 & 0.052 & 0.175 & 0.122 & 0.075 \\
Rangpur (region) & 0.138 & 0.060 & 0.078 & 0.058 & 0.065 & 0.058 \\
Sylhet (region) & 0.116 & 0.017 & 0.007 & 0.071 & 0.008 & 0.012 \\
P.c. total expenditure & 0.067 & 0.091 & 0.098 & 0.078 & 0.089 & 0.087 \\
\hline & 85 & - & - & - & 123 & - \\
\hline
\end{tabular}

For each treatment group, the table reports the average value of the set of confounding variables that have been employed for matching (p.c. total expenditure has been employed as matching variable only for estimating the effect of treatment $\mathrm{C}$ ); ${ }^{\mathrm{a}}$ Indicates that, for migrant households, the variable has been calculated including migrant members; ${ }^{b}$ Indicates that, in the case of migrant households, the variable only accounts for firms that were already active before the migration episode 
Table 3 Balance checks

\begin{tabular}{|c|c|c|c|c|c|c|}
\hline Stratum & Sample & Mean bias & Median bias & Pseudo- $R^{2}$ & LR test & Out of c. support \\
\hline \multicolumn{7}{|c|}{ Overall impact of international migration } \\
\hline \multirow[t]{2}{*}{1} & Unmatched & 28.1 & 25.7 & 0.211 & 0.000 & $5 / 225$ \\
\hline & Matched & 4.9 & 5.8 & 0.012 & 0.953 & \\
\hline \multirow[t]{2}{*}{2} & Unmatched & 24.0 & 22.3 & 0.189 & 0.000 & $8 / 428$ \\
\hline & Matched & 3.4 & 3.3 & 0.006 & 0.966 & \\
\hline \multirow[t]{2}{*}{3} & Unmatched & 29.0 & 25.1 & 0.250 & 0.000 & $21 / 554$ \\
\hline & Matched & 3.0 & 1.9 & 0.004 & 0.985 & \\
\hline \multirow[t]{2}{*}{4} & Unmatched & 24 & 20.2 & 0.229 & 0.000 & $6 / 238$ \\
\hline & Matched & 6.8 & 7.2 & 0.016 & 0.752 & \\
\hline \multicolumn{7}{|c|}{ Impact of the microeconomic transmission channels } \\
\hline \multirow[t]{2}{*}{ A } & Unmatched & 28.8 & 24.9 & 0.252 & 0.000 & $0 / 153$ \\
\hline & Matched & 4.9 & 3.7 & 0.014 & 0.999 & \\
\hline \multirow[t]{2}{*}{ B } & Unmatched & 14.0 & 10.3 & 0.065 & 0.000 & $0 / 154$ \\
\hline & Matched & 2.9 & 2.2 & 0.004 & 0.999 & \\
\hline \multirow[t]{2}{*}{$\mathrm{C}$} & Unmatched & 23.2 & 20.6 & 0.103 & 0.000 & $0 / 122$ \\
\hline & Matched & 4.5 & 4.5 & 0.018 & 0.999 & \\
\hline \multirow[t]{2}{*}{$\mathrm{D}$} & Unmatched & 25.8 & 20.6 & 0.271 & 0.000 & $1 / 952$ \\
\hline & Matched & 2.7 & 1.9 & 0.005 & 0.926 & \\
\hline
\end{tabular}

The table reports standard statistics of matching quality; the households outside the overlapping region (last column) have been dropped

Table 4 ATT of international migration on household food and nutrition security

\begin{tabular}{lcccccc}
\hline FNS indicator & Observed & Counterfactual & ATT & \% Change & SE & $p$ value \\
\hline Caloric intake & & & & & & \\
$\quad$ Per capita caloric intake & 2,587 & 2,312 & 276 & 11.90 & 34.41 & 0.000 \\
$\quad$ Norm. Shannon index & 59.48 & 53.19 & 6.29 & & 0.51 & 0.000 \\
$\quad$ Gini-Simpson index & 54.71 & 48.80 & 5.91 & & 0.45 & 0.000 \\
Food expenditure & & & & & & \\
$\quad$ Per capita food exp. & 55.85 & 44.84 & 11.01 & 24.60 & 1.07 & 0.000 \\
$\quad$ Norm. Shannon index & 75.77 & 72.44 & 3.33 & & 0.39 & 0.000 \\
$\quad$ Gini-Simpson index & 79.99 & 77.05 & 2.94 & & 0.28 & 0.000 \\
\hline
\end{tabular}

The table reports the overall effect of international migration on six household FNS indicators based on caloric intake (kcal/person/day) and food expenditure (taka/person/day)

and Vietnam, two other South Asian developing countries. However, considering that the consumption of tobacco is often associated with gambling and other risky behaviours (McGrath and Barrett 2009), this result may signal unobserved heterogeneity (i.e. that migrant households are somehow 'more responsible' than their non-migrant counterparts), which our empirical strategy is not able to capture. 
Table 5 Food-specific ATTs of international migration on household food intake (kcal/person/day)

\begin{tabular}{|c|c|c|c|c|c|c|c|c|}
\hline \multirow[t]{2}{*}{ Food category } & \multicolumn{2}{|l|}{ Observed } & \multicolumn{2}{|l|}{ Counterfactual } & \multirow{2}{*}{$\begin{array}{l}\% \\
\text { Change }\end{array}$} & \multirow[t]{2}{*}{ ATT } & \multirow[t]{2}{*}{ SE } & \multirow[t]{2}{*}{$p$ value } \\
\hline & Intake (kcal) & $\%$ of total & Intake (kcal) & $\%$ of total & & & & \\
\hline Food grains & 1663.1 & 64.3 & 1599.4 & 69.2 & 4.0 & 63.7 & 23.4 & 0.007 \\
\hline Pulses & 64.4 & 2.5 & 56.6 & 2.4 & 13.7 & 7.8 & 2.2 & 0.000 \\
\hline Fish & 95.8 & 3.7 & 72.5 & 3.1 & 32.2 & 23.3 & 2.2 & 0.000 \\
\hline Eggs & 14.4 & 0.6 & 9.2 & 0.4 & 56.7 & 5.2 & 1.0 & 0.000 \\
\hline Meat & 35.7 & 1.4 & 21.4 & 0.9 & 66.7 & 14.3 & 2.0 & 0.000 \\
\hline Vegetables & 176 & 6.8 & 152.4 & 6.6 & 15.5 & 23.6 & 2.9 & 0.000 \\
\hline Milk and dairy & 45.2 & 1.7 & 25.8 & 1.1 & 75.2 & 19.4 & 2.0 & 0.000 \\
\hline Sweetmeat & 14.7 & 0.6 & 10.2 & 0.4 & 44.3 & 4.5 & 1.4 & 0.002 \\
\hline Oil and fats & 253.4 & 9.8 & 186.5 & 8.1 & 35.9 & 67.0 & 5.1 & 0.000 \\
\hline Fruits & 41.9 & 1.6 & 31.3 & 1.4 & 33.8 & 10.6 & 2.2 & 0.000 \\
\hline Drinks & 2.8 & 0.1 & 1.9 & 0.1 & 52.1 & 1.0 & 0.3 & 0.003 \\
\hline $\begin{array}{l}\text { Sugar and molas- } \\
\text { ses }\end{array}$ & 70.2 & 2.7 & 47.2 & 2.0 & 49.0 & 23.1 & 2.9 & 0.000 \\
\hline $\begin{array}{l}\text { Miscellaneous } \\
\text { food }\end{array}$ & 2.8 & 0.1 & 1.6 & 0.1 & 71.8 & 1.2 & 0.3 & 0.000 \\
\hline $\begin{array}{l}\text { Dining out (food } \\
\text { outside) }\end{array}$ & 22.8 & 0.9 & 27.4 & 1.2 & -16.8 & -4.6 & 2.2 & 0.038 \\
\hline Spices & 74.2 & 2.9 & 59.7 & 2.6 & 24.3 & 14.5 & 1.5 & 0.000 \\
\hline $\begin{array}{l}\text { Betel leas and } \\
\text { chewgoods }\end{array}$ & 10 & 0.4 & 8.6 & 0.4 & 16.2 & 1.4 & 0.5 & 0.006 \\
\hline
\end{tabular}

The table reports the ATT of international migration on household p.c. caloric intake (kcal/person/day) on 16 food categories

We try to better understand this result by regressing per capita tobacco expenditure on migration and a series of household characteristics. Column (1) of Table 7 shows that, after controlling for an appropriate set of observable household characteristics, migrant household members consume significantly less tobacco. Column (2) reports the same regression, but this time the control variables are computed without taking into consideration the characteristics of the migrant members that were abroad at the time of the survey. The coefficient of migration in column (2) is significant and about one-third lower than in column (1), a difference that can be interpreted as the change in tobacco consumption associated with the departure of a male adult member (98.4\% of migrants are male adults), i.e. those who are more likely to consume tobacco (Nargis et al. 2015).

Then, in column (3), we also include a dummy for female-headed households. As a result, the coefficient of migration loses statistical significance while the presence of a female household head turns out to be strongly and negatively associated with the consumption of tobacco. This suggests that the effect of migration is fully mediated by a switch in the household head and highlights a transmission 


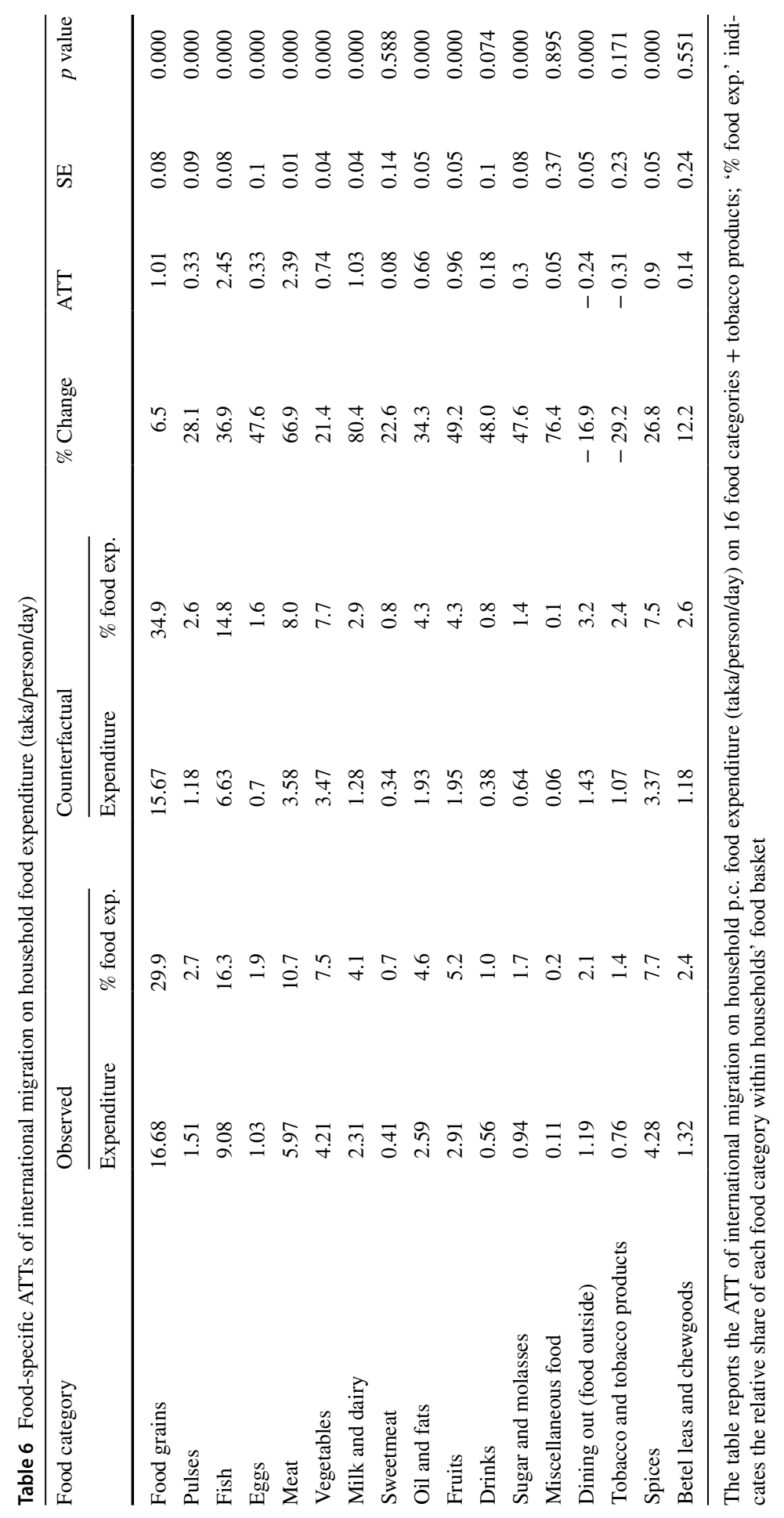


Table 7 Per capita expenditure on tobacco and tobacco products

\begin{tabular}{llllc}
\hline & $(1)$ & $(2)$ & $(3)$ & $(4)$ \\
\hline International migration & $-0.4052^{* * *}$ & $-0.2706^{* * *}$ & -0.0542 & -0.0211 \\
& $(0.0711)$ & $(0.0727)$ & $(0.7463)$ & $(0.0999)$ \\
Female household head & & & $-0.9224^{* * *}$ & $-0.8997^{* * *}$ \\
& & & $(0.0694)$ & $(0.0861)$ \\
International migration $\times$ Female hh head & & & & -0.0971 \\
& & & & $(0.1251)$ \\
Demogr. and socio-eco. ctrls. (migr. incl'd) & Yes & No & No & No \\
Demogr. and socio-eco. ctrls. (migr. excl'd) & No & Yes & Yes & Yes \\
Regional dummies & Yes & Yes & Yes & Yes \\
Urban/rural dummies & Yes & Yes & Yes & Yes \\
Observations & 12,240 & 12,240 & 12,240 & 12,240 \\
$R^{2}$ & 0.0374 & 0.0373 & 0.0502 & 0.0502 \\
\hline
\end{tabular}

The dependent variable is the level of daily p.c. expenditure on 'tobacco and tobacco products' expressed in taka; 'migrants included' indicates that the demographic and socio-economic controls are computed including the characteristics of migrant members (who where not present in the household at the moment of the survey); household demographic controls include the number of female and number of male members divided by age group (18-45, 46-65), the number of elderly members $(65+)$, the number of children (6-17), the number of infants (0-5), squared household size; household socio-economic controls include average education of adult female and male members, a dummy for Muslim household, the presence of a non-agricultural business, a landless dummy and a dummy for a connection to public electricity grid; psu clustered standard errors are reported in parenthesis: $* * * p<0.01, * * p<0.05, * p<0.1$

mechanism, i.e. the shift of household headship to female members, that is often overshadowed by the focus on remittances.

Finally, in column (4), we add an interaction term between migration and female headship. In the presence of unobserved heterogeneity between migrant and nonmigrant households with respect to consumption of tobacco products, we would expect the interaction term to be statistically significant. Since this is not the case, we take this result as support of the overall robustness of our identification strategy.

\section{Microeconomic Transmission Channels Linking International Migration to Household FNS}

In the second part of the analysis, we disentangle the impact of international migration on household FNS, assessing the relevance of the microeconomic transmission channels (Table 8).

Having a member currently abroad and receiving remittances (treatment group ' $\mathrm{D}$ ') is the most frequent case (cf. Table 1). As expected, this treatment turns out to produce a positive and statistically significant effect on both the quantity and variety of the food consumed by household members. Specifically, the households exposed to this treatment are those that exhibit the highest increase in per capita caloric intake, in both relative and absolute terms. The effect on dietary diversity is also positive, substantial and statistically significant. 
Table 8 Disentanglement of effect of migration on household FNS

\begin{tabular}{llllll}
\hline Treatment group & Observed & Counterfactual & ATT & \% Change & $p$ value \\
\hline Per capita caloric intake & & & & & \\
A. Migrants & 2456 & 2402 & 54 & 2.25 & 0.548 \\
B. Remittances & 2503 & 2394 & 109 & 4.54 & 0.171 \\
C. Returnees & 2412 & 2350 & 62 & 2.63 & 0.354 \\
D. Migrants and remittances & 2643 & 2282 & 361 & 15.82 & 0.000 \\
Normalized Shannon index & & & & 0.000 \\
A. Migrants & 61.77 & 52.63 & 9.14 & & 0.010 \\
B. Remittances & 57.66 & 54.60 & 3.05 & & 0.024 \\
C. Returnees & 60.17 & 57.07 & 7.10 & & 0.000 \\
D. Migrants and remittances & 59.25 & 51.65 & & & 0.000 \\
Gini-Simpson index & & & 8.76 & & 0.028 \\
A. Migrants & 56.86 & 48.10 & 2.26 & & 0.041 \\
B. Remittances & 52.84 & 50.58 & 2.49 & & 0.000 \\
C. Returnees & 54.84 & 52.35 & 7.28 & & \\
D. Migrants and remittances & 54.57 & 47.31 & & & \\
\hline
\end{tabular}

The table reports the effect of each transmission channel on three household FNS indicators; caloric intake expressed in kcal/person/day; normalized Shannon and Gini-Simpson Indexes computed on sources of calories

The second largest treatment group consists of remittance-receiving households having no current or previous experience of international migration (treatment group 'B'). Considering that in this case the treatment consists in a simple cash transfer, the signs of the ATTs are expected to be non-negative. They are indeed positive, but the effect is statistically significant only for the indicators of dietary variety. This result can be partly explained by the relatively high counterfactual caloric intake of this treatment group: starting from an already adequate level of caloric intake, these households may prefer to use part of their additional income to increase the variety and quality of their diet rather than just consuming more food than they used to. Secondly, it must be considered that the average value of remittances received by this group of households is lower (about one-third) than the value received by households belonging to the ' $\mathrm{D}$ ' group. Thirdly, since these remittances come from friends or relatives who are outside the household's inner circle, they are more likely to be non-regular transfers made for specific reasons (e.g. gifts, debt repayments) and used by the recipient household mostly for purposes other than food consumption.

Group 'A' is the third largest treatment group and consists of households that currently have some members abroad but have no returnees and do not receive remittances. The effect of this treatment is not statistically significant in terms of per capita caloric intake but is positive and strongly significant for Shannon and Gini-Simpson indexes. These findings suggest that a stand-alone change in households' internal hierarchies is enough to produce, on average, a positive tangible effect on dietary diversity, a proxy for the utilization dimension of FNS. 
The last group (treatment group 'C') comprises those households that have been exposed in the past to international migration but did not have any migrant member abroad and did not receive remittances over the previous 12 months. Consistent with our expectations, the presence of returned migrants does not produce any significant impact on per capita caloric intake but significantly increases the dietary diversity, again a tangible effect on the utilization dimension likely due to the new knowledge/ information brought back home by the returnees.

In general, the findings are largely consistent with the theoretical expectations (cf. Sect. 2). For instance, it is interesting that the 'pure migration' effect (treatment ' $A$ ') and the effect of returned migrants (treatment ' $C$ ') influence only dietary diversity. This is indeed consistent with a change in food utilization due to a change in household composition and to the presence of retuned migrants. At the same time, it is important that the combined effects of migrating and remitting (treatment group ' $\mathrm{D}$ ') is larger than its components (treatment 'A' and treatment ' $\mathrm{B}$ ', separately).

\section{Conclusions}

This paper contributes to the literature by analyzing the linkages between international migration and FNS of left-behind households. We first estimate the overall impact of international migration on the diet of Bangladeshi households, then we assess the impact of the transmission channels on several indicators of FNS.

The estimation of the overall effect suggests that international migration has, on average, a significant and positive impact on all FNS dimensions, enhancing food availability, access and utilization. Specifically, international migrant households have access to a more expensive, diversified and energetic diet. In addition, we show that the increase in food consumption is concentrated on higher-quality products, particularly those richer in animal proteins and micro-nutrients. The assessment of the microeconomic transmission channels on different dimensions of FNS indicates that the average effect of international migration on household FNS is always non-negative. In particular, even though the effect of the treatment 'migration+remittances' turns out to be the most beneficial, all the channels seem to contribute to household FNS by improving diet quantity and variety.

The linkages between migration and FNS need to be adequately considered by policy-makers. The beneficial effects of international migration should be integrated into the FNS agendas of international organizations and governments. Likewise, FNS implications should inform any meaningful discussion on migration and development. Taking properly into account the effects of migration on FNS can, for instance, contribute to the design of more effective policies aimed at achieving the UN-SDG 2 of 'Zero hunger'. On the one hand, FNS policy interventions may include measures aimed to reduce, when possible, the frictions that may weaken the bond between migrants and their households of origin that could jeopardize the expected beneficial effects of migration. On the other hand, since 
the household size is highly correlated with the probability of sending migrants abroad, pro-poor migration policies should also be coupled with specific interventions targeting smaller-size households for whom migration represents a less viable/attractive strategy.

Finally, with specific reference to Bangladesh, our research contributes to shed some further light on the so-called Bangladesh paradox. Indeed, given the nexus between FNS and health outcomes, our results suggest that also international migration could have contributed to Bangladesh's remarkable improvements in health and nutrition that occurred during a period of relatively weak economic growth.

Acknowledgements We would like to thank the two anonymous referees for their careful reading of our paper, constructive comments and helpful suggestions.

\section{Compliance with ethical standards}

Conflict of interest statement On behalf of all authors, the corresponding author states that there is no conflict of interest.

\section{Appendix}

See Tables 9, 10, 11, and 12. 
Table 9 Within-stratum probit regressions

\begin{tabular}{|c|c|c|c|c|}
\hline & Block 1 & Block 2 & Block 3 & Block 4 \\
\hline Adults 18-45 (male) & $\begin{array}{l}0.418 * * * \\
(0.0547)\end{array}$ & $\begin{array}{l}0.648 * * * \\
(0.0440)\end{array}$ & $\begin{array}{l}0.523 * * * \\
(0.0387)\end{array}$ & $\begin{array}{l}0.626 * * * \\
(0.0573)\end{array}$ \\
\hline Adults 46-65 (male) & $\begin{array}{l}0.412 * * * \\
(0.0887)\end{array}$ & $\begin{array}{l}0.354 * * * \\
(0.0675)\end{array}$ & $\begin{array}{l}0.390^{* * *} \\
(0.0654)\end{array}$ & $\begin{array}{l}0.488 * * * \\
(0.0949)\end{array}$ \\
\hline Adults 18-45 (female) & $\begin{array}{r}-0.111 \\
(0.0715)\end{array}$ & $\begin{array}{r}-0.116^{* *} \\
(0.0546)\end{array}$ & $\begin{array}{c}0.0223 \\
(0.0490)\end{array}$ & $\begin{array}{r}-0.0745 \\
(0.0767)\end{array}$ \\
\hline Adults 46-65 (female) & $\begin{array}{c}0.067 \\
(0.0938)\end{array}$ & $\begin{array}{c}0.124 * \\
(0.0667)\end{array}$ & $\begin{array}{l}0.233 * * * \\
(0.0671)\end{array}$ & $\begin{array}{l}0.199 * * \\
(0.100)\end{array}$ \\
\hline Adults 65+ & $\begin{array}{c}0.223 * * \\
(0.0876)\end{array}$ & $\begin{array}{l}0.310 * * * \\
(0.0605)\end{array}$ & $\begin{array}{l}0.165 * * \\
(0.0689)\end{array}$ & $\begin{array}{l}0.246 * * \\
(0.115)\end{array}$ \\
\hline Children 6-17 & $\begin{array}{l}0.0844 * * \\
(0.0346)\end{array}$ & $\begin{array}{c}0.0194 \\
(0.0267)\end{array}$ & $\begin{array}{c}0.0454 * \\
(0.0250)\end{array}$ & $\begin{array}{l}0.0679 * \\
(0.0401)\end{array}$ \\
\hline Schooling (males) & $\begin{array}{c}-0.0554 * * * \\
(0.0128)\end{array}$ & $\begin{array}{c}-0.0768 * * * \\
(0.00965)\end{array}$ & $\begin{array}{c}-0.0623 * * * \\
(0.00829)\end{array}$ & $\begin{array}{c}-0.118 * * * \\
(0.0124)\end{array}$ \\
\hline Schooling (females) & $\begin{array}{l}0.0746^{* * * *} \\
(0.0149)\end{array}$ & $\begin{array}{l}0.0587 * * * \\
(0.0108)\end{array}$ & $\begin{array}{l}0.0830 * * * \\
(0.00978)\end{array}$ & $\begin{array}{l}0.118 * * * \\
(0.0141)\end{array}$ \\
\hline Muslim & $\begin{array}{l}1.020 * * * \\
(0.176)\end{array}$ & $\begin{array}{l}0.502^{* * *} \\
(0.140)\end{array}$ & $\begin{array}{l}0.679 * * * \\
(0.101)\end{array}$ & $\begin{array}{l}0.426^{* * *} \\
(0.169)\end{array}$ \\
\hline Entrepreneurship (formal) & $\begin{array}{r}-0.073 \\
(0.164)\end{array}$ & $\begin{array}{c}-0.401 * * \\
(0.156)\end{array}$ & $\begin{array}{c}-0.591 * * * \\
(0.126)\end{array}$ & $\begin{array}{c}-1.030 * * * \\
(0.202)\end{array}$ \\
\hline Entrepreneurship (informal) & $\begin{array}{c}-0.583 * * * \\
(0.126)\end{array}$ & $\begin{array}{c}-0.539 * * * \\
(0.0895)\end{array}$ & $\begin{array}{c}-0.536 * * * \\
(0.0898)\end{array}$ & $\begin{array}{c}-0.374 * * * \\
(0.124)\end{array}$ \\
\hline Access to elec. grid & $\begin{array}{l}0.575 * * * \\
(0.0937)\end{array}$ & $\begin{array}{l}0.479 * * * \\
(0.0600)\end{array}$ & $\begin{array}{l}0.699 * * * \\
(0.0756)\end{array}$ & $\begin{array}{l}0.409 * * * \\
(0.157)\end{array}$ \\
\hline Sample weights & $\begin{array}{c}-0.000566^{* * *} * \\
(0.000120)\end{array}$ & $\begin{array}{c}-0.000392 * * * \\
(0.0000674)\end{array}$ & $\begin{array}{c}-0.00131 * * * \\
(0.000226)\end{array}$ & $\begin{array}{c}-0.0000548 * * * \\
(0.0000174)\end{array}$ \\
\hline Urban & $\begin{array}{c}-1.456 * * * \\
(0.226)\end{array}$ & $\begin{array}{c}-1.330 * * * \\
(0.288)\end{array}$ & $\begin{array}{c}-3.292 * * * \\
(0.430)\end{array}$ & Omitted \\
\hline Landless & $\begin{array}{r}-0.591 * \\
(0.305)\end{array}$ & $\begin{array}{r}-0.247 \\
(0.191)\end{array}$ & $\begin{array}{r}-0.281^{*} \\
(0.153)\end{array}$ & $\begin{array}{c}-0.453 * * * \\
(0.152)\end{array}$ \\
\hline Constant & $\begin{array}{c}-1.642 * * * \\
(0.383)\end{array}$ & $\begin{array}{c}-1.435^{* * * *} \\
(0.269)\end{array}$ & $\begin{array}{l}1.347 * * \\
(0.668)\end{array}$ & $\begin{array}{c}-2.467 * * * \\
(0.254)\end{array}$ \\
\hline Observations & 2,479 & 4,817 & 3,318 & 1,620 \\
\hline Pseudo- $R^{2}$ & 0.211 & 0.189 & 0.25 & 0.229 \\
\hline
\end{tabular}

Each column reports the probit regression used for the estimation of the linearized propensity score for each stratum in the first part of the analysis; robust SE in parenthesis; ${ }^{* *} p<0.01,{ }^{* *} p<0.05,{ }^{*} p<0.1$ 
Table 10 Probit regressions for multiple treatment analysis

\begin{tabular}{|c|c|c|c|c|}
\hline & A. Migrants & B. Remittances & C. Returnees & D. Migr. + Rem. \\
\hline Adults 18-45 (male) & $\begin{array}{l}0.520^{* * * *} \\
(0.0472)\end{array}$ & $\begin{array}{r}-0.136^{* *} \\
(0.0554)\end{array}$ & $\begin{array}{l}0.161 * * * \\
(0.0522)\end{array}$ & $\begin{array}{l}0.645 * * * \\
(0.0274)\end{array}$ \\
\hline Adults 46-65 (male) & $\begin{array}{l}0.468 * * * \\
(0.0852)\end{array}$ & $\begin{array}{c}-0.033 \\
(0.0779)\end{array}$ & $\begin{array}{c}0.0408 \\
(0.0832)\end{array}$ & $\begin{array}{l}0.452 * * * \\
(0.0447)\end{array}$ \\
\hline Adults 18-45 (female) & $\begin{array}{r}-0.129 * * \\
(0.0642)\end{array}$ & $\begin{array}{c}0.0337 \\
(0.0616)\end{array}$ & $\begin{array}{c}0.0266 \\
(0.0673)\end{array}$ & $\begin{array}{c}-0.111^{* * * *} \\
(0.0346)\end{array}$ \\
\hline Adults 46-65 (female) & $\begin{array}{c}0.149 * \\
(0.0872)\end{array}$ & $\begin{array}{c}0.0175 \\
(0.0799)\end{array}$ & $\begin{array}{r}-0.0313 \\
(0.0895)\end{array}$ & $\begin{array}{l}0.196 * * * \\
(0.0452)\end{array}$ \\
\hline Adults $65+$ & $\begin{array}{l}0.191 * * \\
(0.0850)\end{array}$ & $\begin{array}{c}0.143^{* *} \\
(0.0713)\end{array}$ & $\begin{array}{l}0.125 \\
(0.0825)\end{array}$ & $\begin{array}{l}0.251 * * * \\
(0.0444)\end{array}$ \\
\hline Children 6-17 & $\begin{array}{c}0.0209 \\
(0.0328)\end{array}$ & $\begin{array}{c}0.0127 \\
(0.0295)\end{array}$ & $\begin{array}{c}0.00621 \\
(0.0329)\end{array}$ & $\begin{array}{l}0.0684 * * * \\
(0.0173)\end{array}$ \\
\hline Schooling (males) & $\begin{array}{c}-0.0857 * * * \\
(0.0123)\end{array}$ & $\begin{array}{r}-0.0158^{*} \\
(0.00943)\end{array}$ & $\begin{array}{c}0.00294 \\
(0.0109)\end{array}$ & $\begin{array}{c}-0.0929 * * * \\
(0.00626)\end{array}$ \\
\hline Schooling (females) & $\begin{array}{l}0.0881^{* * *} \\
(0.0134)\end{array}$ & $\begin{array}{l}0.0447 * * * \\
(0.0111)\end{array}$ & $\begin{array}{l}0.0412 * * * \\
(0.0130)\end{array}$ & $\begin{array}{l}0.0814 * * * \\
(0.00694)\end{array}$ \\
\hline Muslim & $\begin{array}{l}0.477 * * * \\
(0.147)\end{array}$ & $\begin{array}{l}0.381^{* * *} \\
(0.128)\end{array}$ & $\begin{array}{l}0.311^{* *} \\
(0.134)\end{array}$ & $\begin{array}{l}0.672 * * * \\
(0.0820)\end{array}$ \\
\hline Entrepreneurship (formal) & $\begin{array}{c}-0.489 * * * \\
(0.183)\end{array}$ & $\begin{array}{r}0.0018 \\
(0.132)\end{array}$ & $\begin{array}{c}-0.191 \\
(0.151)\end{array}$ & $\begin{array}{c}-0.584 * * * \\
(0.0955)\end{array}$ \\
\hline Entrepreneurship (informal) & $\begin{array}{c}-0.619 * * * \\
(0.134)\end{array}$ & $\begin{array}{c}0.0214 \\
(0.0849)\end{array}$ & $\begin{array}{c}0.0602 \\
(0.0910)\end{array}$ & $\begin{array}{c}-0.758 * * * \\
(0.0690)\end{array}$ \\
\hline Access to elec. grid & $\begin{array}{l}0.513 * * * \\
(0.0932)\end{array}$ & $\begin{array}{l}0.277 * * * \\
(0.0791)\end{array}$ & $\begin{array}{l}0.358 * * * \\
(0.0968)\end{array}$ & $\begin{array}{l}0.512 * * * \\
(0.0471)\end{array}$ \\
\hline Sample weights & $\begin{array}{c}-0.0000838 * * \\
(0.0000388)\end{array}$ & $\begin{array}{c}-0.000166^{* * * *} \\
(0.0000504)\end{array}$ & $\begin{array}{c}0.0000315 \\
(0.0000255)\end{array}$ & $\begin{array}{c}-0.0000453^{* * *} \\
(0.0000179)\end{array}$ \\
\hline Urban & $\begin{array}{c}-0.420^{* * * *} \\
(0.104)\end{array}$ & $\begin{array}{c}-0.416^{* * *} \\
(0.119)\end{array}$ & $\begin{array}{r}-0.152^{*} \\
(0.0853)\end{array}$ & $\begin{array}{c}-0.297 * * * \\
(0.0506)\end{array}$ \\
\hline Regional dummies & Yes & Yes & Yes & Yes \\
\hline Landless & $\begin{array}{r}-0.0605 \\
(0.173)\end{array}$ & $\begin{array}{r}-0.360 * \\
(0.185)\end{array}$ & $\begin{array}{c}-0.500 * * \\
(0.209)\end{array}$ & $\begin{array}{c}-0.370^{* * * *} \\
(0.104)\end{array}$ \\
\hline P.c. total expenditure & & & $\begin{array}{c}0.000289 \\
(0.000397)\end{array}$ & \\
\hline Constant & $\begin{array}{c}-3.200^{* * * *} \\
(0.230)\end{array}$ & $\begin{array}{c}-2.199 * * * \\
(0.230)\end{array}$ & $\begin{array}{c}-3.194 * * * \\
(0.203)\end{array}$ & $\begin{array}{c}-2.827 * * * \\
(0.120)\end{array}$ \\
\hline Observations & 10,942 & 10,943 & 11,741 & 10,912 \\
\hline Pseudo- $R^{2}$ & 0.252 & 0.0646 & 0.271 & 0.103 \\
\hline
\end{tabular}

Notes: Each column reports the probit regression used for the estimation of the linearized propensity score for the multiple treatments in the second part of the analysis; robust S.E. in parenthesis; $* * * p$ $<0.01, * * p<0.05, * p<0.1$ 
Table 11 ATT of international migration (alternative matching estimators)

\begin{tabular}{|c|c|c|c|c|}
\hline FNS indicator & Observed & Counterfactual & ATT & SE \\
\hline \multicolumn{5}{|l|}{ (A) Nearest neighbour } \\
\hline \multicolumn{5}{|l|}{ Caloric intake } \\
\hline P.c. caloric intake (kcal) & 2587 & 2282 & $305^{* * *}$ & 39 \\
\hline Norm. Shannon index & 59.55 & 52.69 & $6.86^{* * *}$ & 0.51 \\
\hline Gini-Simpson index & 54.73 & 49.34 & $5.40^{* * *}$ & 0.54 \\
\hline \multicolumn{5}{|l|}{ Food expenditure } \\
\hline P.c. food expenditure & 55.89 & 44.34 & $11.54 * * *$ & 1.18 \\
\hline Norm. Shannon index & 75.78 & 72.75 & $3.03 * * *$ & 0.49 \\
\hline Gini-Simpson index & 75.89 & 72.36 & $2.65^{* * *}$ & 0.35 \\
\hline \multicolumn{5}{|l|}{ (B) Kernel } \\
\hline \multicolumn{5}{|l|}{ Caloric intake } \\
\hline P.c. caloric intake (kcal) & 2586 & 2319 & $267 * * *$ & 32 \\
\hline Norm. Shannon index & 59.40 & 53.08 & $6.31 * * *$ & 0.45 \\
\hline Gini-Simpson index & 54.66 & 48.71 & $5.95^{* * *}$ & 0.40 \\
\hline \multicolumn{5}{|l|}{ Food expenditure } \\
\hline P.c. food expenditure & 55.63 & 44.68 & $10.95 * * *$ & 1.00 \\
\hline Norm. Shannon index & 75.70 & 72.56 & $3.14 * * *$ & 0.35 \\
\hline Gini-Simpson index & 79.95 & 77.15 & $2.80^{* * *}$ & 0.25 \\
\hline \multicolumn{5}{|l|}{ (C) Radius (0.15) } \\
\hline \multicolumn{5}{|l|}{ Caloric intake } \\
\hline P.c. caloric intake (kcal) & 2587 & 2327 & $260 * * *$ & 32 \\
\hline Norm. Shannon index & 59.51 & 53.24 & $6.27 * * *$ & 0.45 \\
\hline Gini-Simpson index & 54.73 & 48.79 & $5.94 * * *$ & 0.40 \\
\hline \multicolumn{5}{|l|}{ Food expenditure } \\
\hline P.c. food expenditure & 55.89 & 45.04 & $10.85 * * *$ & 1.00 \\
\hline Norm. Shannon index & 75.78 & 72.77 & $3.01 * * *$ & 0.34 \\
\hline Gini-Simpson index & 80.00 & 77.27 & $2.72^{* * *}$ & 0.25 \\
\hline
\end{tabular}

This table reports the ATT of international migration on a set household FNS indicators estimated following the within-statum matching strategy but employing different estimators: simple nearest neighbour (A), kernel estimator (B) and radius estimator (C); ${ }^{*} p<0.1,{ }^{*} p<0.05, * * * p<0.01$ 
Table 12 ATT of international migration (alternatives to stratification)

\begin{tabular}{|c|c|c|c|c|}
\hline FNS indicator & Observed & Counterfactual & ATT & SE \\
\hline \multicolumn{5}{|c|}{ (A) Matching using regional dummies } \\
\hline \multicolumn{5}{|c|}{ Caloric intake } \\
\hline P.c. caloric intake (kcal) & 2582 & 2322 & $259 * * *$ & 33.61 \\
\hline Norm. Shannon index & 59.55 & 52.69 & $6.86^{* * *}$ & 0.51 \\
\hline Gini-Simpson index & 54.75 & 48.28 & $6.47^{* * *}$ & 0.45 \\
\hline \multicolumn{5}{|l|}{ Food expenditure } \\
\hline P.c. food expenditure & 55.80 & 45.04 & $10.76^{* * *}$ & 1.09 \\
\hline Norm. Shannon index & 75.89 & 72.36 & $3.53 * * *$ & 0.39 \\
\hline Gini-Simpson index & 80.06 & 77.00 & $3.06 * * *$ & 0.27 \\
\hline \multicolumn{5}{|c|}{ (B) Matching using food poverty line } \\
\hline \multicolumn{5}{|l|}{ Caloric intake } \\
\hline P.c. caloric intake (kcal) & 2583 & 2310 & $274 * * *$ & 33.34 \\
\hline Norm. Shannon index & 59.53 & 52.68 & $6.85^{* * *}$ & 0.44 \\
\hline Gini-Simpson index & 54.73 & 48.36 & $6.36^{* * *}$ & 0.49 \\
\hline \multicolumn{5}{|l|}{ Food expenditure } \\
\hline P.c. food expenditure & 55.86 & 43.95 & $11.91 * * *$ & 0.67 \\
\hline Norm. Shannon index & 75.87 & 72.06 & $3.81 * * *$ & 0.38 \\
\hline Gini-Simpson index & 80.05 & 76.81 & $3.24 * * *$ & 0.27 \\
\hline
\end{tabular}

This table reports the ATT of international migration on a set household FNS indicators estimated following matching strategies alternative to within-statum matching: the results of panel (A) are obtained including regional dummies (13 units out of common support, dropped), those of panel (B) by including the regional food poverty line among regressors (14 units out of common support, dropped); ${ }^{*} p<0.1$, $* * p<0.05, * * * p<0.01$

\section{References}

Abdulloev, I., I.N. Gang, and M.-S. Yun. 2014. Migration, education and the gender gap in labour force participation. The European Journal of Development Research 26 (4): 509-526.

Adams, R.H.J. 2011. Evaluating the economic impact of international remittances on developing countries using household surveys: A literature review. Journal of Development Studies 47 (6): 809-828.

Adams, R.H.J., and A. Cuecuecha. 2010. Remittances, household expenditure and investment in Guatemala. World Development 38 (11): 1626-1641.

Adams, R.H.J., and A. Cuecuecha. 2013. The impact of remittances on investment and poverty in Ghana. World Development 50: 24-40.

Alam, S. 2012. The effect of gender-based returns to borrowing on intra-household resource allocation in rural Bangladesh. World Development 40 (6): 1164-1180.

Arimond, M., and M.T. Ruel. 2004. Dietary diversity is associated with child nutritional status: Evidence from 11 demographic and health surveys. The Journal of Nutrition 134 (10): 2579-2585.

Asadullah, M.N., A. Savoia, and W. Mahmud. 2014. Paths to development: Is there a Bangladesh surprise? World Development 62: 138-154.

Austin, P.C. 2011. Optimal caliper widths for propensity-score matching when estimating differences in means and differences in proportions in observational studies. Pharmaceutical Statistics 10 (2): $150-161$.

Azzarri, C., and A. Zezza. 2011. International migration and nutritional outcomes in Tajikistan. Food Policy 36 (1): 54-70.

Barham, B., and S. Boucher. 1998. Migration, remittances, and inequality: Estimating the net effects of migration on income distribution. Journal of Development Economics 55 (2): 307-331. 
Bertoli, S., and F. Marchetta. 2014. Migration, remittances and poverty in Ecuador. The Journal of Development Studies 50 (8): 1067-1089.

Bertoli, S., and E. Murard. 2019. Migration and co-residence choices: Evidence from Mexico. Journal of Development Economics, forthcoming.

Böhme, M.H., R. Persian, and T. Stöhr. 2015. Alone but better off? Adult child migration and health of elderly parents in Moldova. Journal of Health Economics 39: 211-227.

Bryan, G., S. Chowdhury, and A.M. Mobarak. 2014. Underinvestment in a profitable technology: The case of seasonal migration in Bangladesh. Econometrica 82 (5): 1671-1748.

Buvinić, M., and G.R. Gupta. 1997. Female-headed households and female-maintained families: Are they worth targeting to reduce poverty in developing countries? Economic Development and Cultural Change 45 (2): 259-280.

Calero, C., A.S. Bedi, and R. Sparrow. 2009. Remittances, liquidity constraints and human capital investments in Ecuador. World Development 37 (6): 1143-1154.

Carletto, C., A. Zezza, and R. Banerjee. 2013. Towards better measurement of household food security: Harmonizing indicators and the role of household surveys. Global Food Security 2 (1): 30-40.

Chowdhury, A.M.R., A. Bhuiya, M.E. Chowdhury, S. Rasheed, Z. Hussain, and L.C. Chen. 2013. The Bangladesh paradox: Exceptional health achievement despite economic poverty. The Lancet 382 (9906): 1734-1745.

Cox, D.R. 1992. Causality: Some statistical aspects. Journal of the Royal Statistical Society 155 (2): $291-301$.

Crush, J. 2013. Linking food security, migration and development. International Migration 51 (5): 61-75.

De Haen, H., S. Klasen, and M. Qaim. 2011. What do we really know? Metrics for food insecurity and undernutrition. Food Policy 36 (6): 760-769.

Giannelli, G.C., and L. Mangiavacchi. 2010. Children's schooling and parental migration: Empirical evidence on the 'left-behind' generation in Albania. Labour 24: 76-92.

Haddad, L., J. Hoddinott, and H. Alderman. 1997. Intrahousehold resource allocation in developing countries: Models, methods, and policies. Baltimore: Johns Hopkins University Press.

Ham, J.C., X. Li, and P.B. Reagan. 2011. Matching and semi-parametric IV estimation, a distance-based measure of migration, and the wages of young men. Journal of Econometrics 161 (2): 208-227.

Headey, D., J. Hoddinott, D. Ali, R. Tesfaye, and M. Dereje. 2015. The other asian enigma: Explaining the rapid reduction of undernutrition in Bangladesh. World Development 66: 749-761.

Headey, D.D. 2013. Developmental drivers of nutritional change: A cross-country analysis. World Development 42: 76-88.

Hoddinott, J., and Y. Yohannes. 2002. Dietary diversity as a food security indicator. IFPRI Discussion Paper No. 136.

Imbens, G.W., and D.B. Rubin. 2015. Causal inference in statistics, social, and biomedical sciences. Cambridge: Cambridge University Press.

IOM. 2018. World Migration Report 2018. Geneva: International Organization for Migration.

Jimenez-Soto, E., and R. Brown. 2012. Assessing the poverty impacts of migrants' remittances using propensity score matching: The case of Tonga. Economic Record 88 (282): 425-439.

Kabeer, N., S. Mahmud, and S. Tasneem. 2018. The contested relationship between paid work and women's empowerment: Empirical analysis from Bangladesh. The European Journal of Development Research 30 (2): 235-251.

Karamba, W.R., E.J. Quiñones, and P. Winters. 2011. Migration and food consumption patterns in Ghana. Food Policy 36 (1): 41-53.

Lechner, M. 2002. Program heterogeneity and propensity score matching: An application to the evaluation of active labor market policies. Review of Economics and Statistics 84 (2): 205-220.

Levitt, P. 1998. Social remittances: Migration driven local-level forms of cultural diffusion. International Migration Review 32 (4): 926-948.

Lokshin, M., M. Bontch-Osmolovski, and E. Glinskaya. 2010. Work-related migration and poverty reduction in Nepal. Review of Development Economics 14 (2): 323-332.

Mangiavacchi, L., F. Perali, and L. Piccoli. 2018. Intrahousehold distribution in migrant-sending families. Journal of Demographic Economics 84 (1): 107-148.

Masset, E. 2011. A review of hunger indices and methods to monitor country commitment to fighting hunger. Food Policy 36: S102-S108.

McGrath, D.S., and S.P. Barrett. 2009. The comorbidity of tobacco smoking and gambling: A review of the literature. Drug and Alcohol Review 28 (6): 676-681. 
McKenzie, D., S. Stillman, and J. Gibson. 2010. How important is selection? Experimental vs. non-experimental measures of the income gains from migration. Journal of the European Economic Association 8 (4): 913-945.

Mehlum, H., and G. Østenstad. 2016. The political economy of migration policies in oil-rich Gulf countries. Oxford Economic Papers 68 (4): 1062-1083.

Mendola, M. 2008. Migration and technological change in rural households: Complements or substitutes? Journal of Development Economics 85 (1-2): 150-175.

Möllers, J., and W. Meyer. 2014. The effects of migration on poverty and inequality in rural Kosovo. IZA Journal of Labor \& Development 3 (1): 16.

Nargis, N., M.E. Thompson, G.T. Fong, P. Driezen, A.G. Hussain, U.H. Ruthbah, A.C. Quah, and A.S. Abdullah. 2015. Prevalence and patterns of tobacco use in Bangladesh from 2009 to 2012: Evidence from international tobacco control (ITC) study. PLOS ONE 10 (11): e0141135.

Nguyen, C.V., and A. Tran. 2014. Do international remittances matter to tobacco spending? Evidence from Vietnam. The European Journal of Development Research 26 (5): 629-650.

Nguyen, M.C., and P. Winters. 2011. The impact of migration on food consumption patterns: The case of Vietnam. Food Policy 36 (1): 71-87.

Quisumbing, A. 2003. Household decisions, gender, and development. Washington, DC: IFPRI.

Quisumbing, A., and S. McNiven. 2010. Moving forward, looking back: The impact of migration and remittances on assets, consumption, and credit constraints in the rural Philippines. The Journal of Development Studies 46 (1): 91-113.

Rosenbaum, P.R., and D.B. Rubin. 1983. The central role of the propensity score in observational studies for causal effects. Biometrika 70 (1): 41-55.

Rubin, D.B. 2001. Using propensity scores to help design observational studies: Application to the tobacco litigation. Health Services and Outcomes Research Methodology 2 (3-4): 169-188.

Stark, O., and D.E. Bloom. 1985. The new economics of labor migration. The American Economic Review 75 (2): 173-178.

Thorne-Lyman, A.L., N. Valpiani, K. Sun, R.D. Semba, C.L. Klotz, K. Kraemer, N. Akhter, S. de Pee, R. Moench-Pfanner, M. Sari, et al. 2009. Household dietary diversity and food expenditures are closely linked in rural Bangladesh, increasing the risk of malnutrition due to the financial crisis. The Journal of Nutrition 140 (1): 182S-188S.

Wagle, U.R., and S. Devkota. 2018. The impact of foreign remittances on poverty in Nepal: A panel study of household survey data, 1996-2011. World Development 110: 38-50.

Warner, K., and T. Afifi. 2014. Where the rain falls: Evidence from 8 countries on how vulnerable households use migration to manage the risk of rainfall variability and food insecurity. Climate and Development 6 (1): 1-17.

Welter, F. 2011. Contextualizing entrepreneurship-Conceptual challenges and ways forward. Entrepreneurship Theory and Practice 35 (1): 165-184.

World Bank. 2018. World development indicators. Washington, DC: World Bank.

Yang, D. 2008. International migration, remittances and household investment: Evidence from Philippine migrants' exchange rate shocks. The Economic Journal 118 (528): 591-630.

Zanutto, E.L. 2006. A comparison of propensity score and linear regression analysis of complex survey data. Journal of Data Science 4 (1): 67-91.

Zezza, A., C. Carletto, B. Davis, and P. Winters. 2011. Assessing the impact of migration on food and nutrition security. Food Policy 36 (1): 1-6.

Zhang, X., S. Rashid, K. Ahmad, and A. Ahmed. 2014. Escalation of real wages in Bangladesh: Is it the beginning of structural transformation? World Development 64: 273-285.

Zhunusova, E., and R. Herrmann. 2018. Development impacts of international migration on 'sending' communities: The case of rural Kyrgyzstan. The European Journal of Development Research 30 (5): 871-891.

Publisher's Note Springer Nature remains neutral with regard to jurisdictional claims in published maps and institutional affiliations. 